\title{
PREDIKSI KASUS COVID-19 DI INDONESIA MENGGUNAKAN METODE BACKPROPAGATION DAN FUZZY TSUKAMOTO
}

\author{
Fra Siskus Dian Arianto ${ }^{1}$, Noviyanti $\mathrm{P}^{2}$ \\ Magister Matematika Universitas Diponegoro ${ }^{1}$ \\ Jl. Prof. Sudharto, SH Tembalang 50275 \\ Magister Teknik Informatika Universitas AMIKOM Yogyakarta ${ }^{2}$ \\ Jl. Ringroad, Condongcatur, Sleman, DIY 55283 \\ dian.arianto2011@gmail.com, novi.jiuu94@gmail.com
}

\begin{abstract}
Pandemic COVID-19 has so far not subsided. This outbreak has spread to almost all countries in the world. As a result of this pandemic community activity and economy has decreased. The COVID-19 pandemic itself appeared in Indonesia precisely on March 2, 2020. 2 people tested positive for being infected with COVID-19 so that it was referred to as case 1 and case 2. After being detected a pandemic COVID-19 in Indonesia, Indonesia experienced an increase in cases every day positive COVID-19. The purpose of this research is to be able to obtain models in predicting the addition of COVID-19 cases in Indonesia based on time series data. In this research, the development of the Fuzzy Tsukamoto method is carried out to produce learning rate momentum which is then used in building network architecture in the Backpropagation method and produces a prediction model for adding COVID-19 cases in Indonesia. The model produced by conducting a network architecture experiment is the R-value (correlation coefficient) of 0.84278 and the prediction simulation produces an

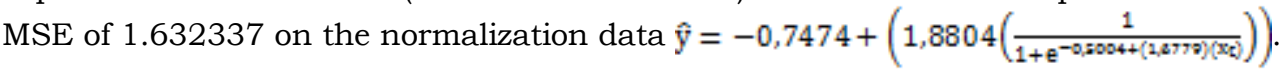

Keywords - Case COVID-19, Backpropagation Method, Tsukamoto Fuzzy Method, Prediction of COVID-19 cases.

\begin{abstract}
Abstrak - Pandemic COVID-19 sampai saat ini belum mereda. Wabah ini telah meluas dihampir seluruh negara didunia. Akibat dari pandemic ini aktivitas dan perekonomian masyarakat mengalami penurunan. Pandemic COVID-19 ini sendiri muncul di Indonesia tepatnya pada 2 Maret 2020. Terdapat 2 orang yang dinyatakan positif terinfeksi COVID-19 sehingga disebut sebagai kasus 1 dan kasus 2. Setelah terdeteksi adanya pandemic COVID-19 di Indonesia, setiap harinya Indonesia mengalami penambahan kasus positif COVID-19. Tujuan dilakukannya penelitian ini adalah untuk dapat memperoleh model dalam memprediksi penambahan kasus COVID-19 di Indonesia berdasarkan pada data time series. Pada penelitian ini dilakukan pengembangan terhadap metode Fuzzy Tsukamoto untuk menghasilkan learning rate momentum yang kemudian digunakan dalam membangun arsitektur jaringan pada metode Backpropagation dan menghasilkan sebuah model prediksi penambahan kasus COVID-19 di Indonesia. Model yang dihasilkan dengan melakukan 1 kali

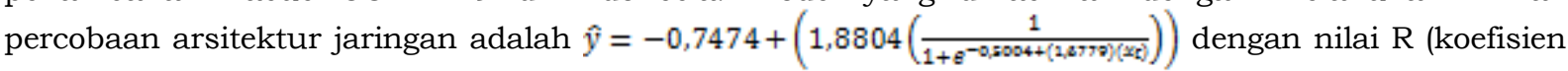
korelasi) sebesar 0,84278 dan simulasi prediksi menghasilkan MSE sebesar 1,632337 pada data normalisasi.

Kata Kunci - Kasus COVID-19, Metode Backpropagation, Metode Fuzzy Tsukamoto, Prediksi kasus COVID-19.
\end{abstract}

\section{PENDAHULUAN}

Saat ini dunia tengah dilanda wabah yang sangat serius, yaitu wabah pandemic Corona Virus atau disebut juga dengan COVID-19. Pandemic COVID-19 ini telah meluas kehampir seluruh negara didunia. Pandemic ini meluas dengan sangat cepat karena penyebarannya terjadi dari manusia ke manusia.

Sampai saat ini belum ditemukan obat atau vaksin yang dapat digunakan untuk mengatasi penyebaran pandemic COID-19. Masyarakat dianjurkan untuk tetap dirumah saja dan tidak keluar rumah kecuali dalam keadaan darurat.

Di Indonesia pandemic COVID-19 terdeteksi pada awal bulan maret tepatnya tanggal 2 Maret 2020
Pada tanggal 2 Maret 2020 terdeteksi 2 orang yang dinyatakan positif COVID-19 sehingga disebut kasus 1 dan kasus 2 [1].

Berawal dari kedua kasus tersebut, terjadi penambahan kasus positif COVID-19 disetiap harinya. Kasus penambahan ditiap harinya tidak dapat diperkirakan jumlahnya sehingga penangganan seperti menyediakan layanan, fasilitas, dan tenaga medis tak dapat diprediksi.

Dari kasus tersebut, maka peneliti melakukan penelitian dengan mengangkat judul tentang "Prediksi Kasus COVID-19 di Indonesia menggunakan Backpropagation dan Fuzzy Tsukamoto. Penelitian dilakukan dengan tujuan untuk memperoleh model 
dalam memprediksi penambahan kasus COVID-19 di Indonesia.

\section{A. Pandemic COVID-19}

Corona Virus atau COVID-19 pertama kali muncul pada akhir Desember 2019 di kota Wuhan, provinsi Hubei Cina. Pada 11 Maret 2020 Organisasi Kesehatan Dunia (WHO) mendeklarasikan virus corona novel 2019 sebagai global pandemi. Seseorang yang terjangkit virus ini akan menunjukkan gejala ringan seperti gejala flu, sehingga menyebabkan virus ini kesulitan untuk dideteksi. Virus COVID-19 menyerang bagian pernapasan, sehingga menyebabkan penderitanya kesulitan bernafas [2].

Sampai saat ini belum ditemukan vaksin dan obat untuk mecegah penyebaran COVID-19. Satu-satunya cara untuk dapat mengurangi penyebaran pandemic ini adalah dengan berdiam diri dirumah, tidak berada dikeramaian, rajin mencuci tangan sebelum dan sesudah melakukan aktivitas, dan selalu menggunakan masker.

Di Indonesia kasus COVID-19 terus mengalami penambahan dan tidak dapat dipastikan kapan wabah pandemic COVID-19 ini dapat berakhir.

\section{B. Data Time Series}

Data time series atau deret waktu merupakan data yang berurutan disetiap waktu. Salah satu contoh data time series yang dapat digunakan untuk melakukan prediksi adalah sebuah data yang disajikan per hari secara berurutan. Terdapat beberapa penelitian yang menjadi acuan dilakukannya penelitian ini, yaitu penelitian [3] melakukan penelitian menggunakan data time series. Penelitian ini menggunakan model statistik untuk menguji database time series. Penelitian ini menggunakan algoritma hybrid dengan menggabungkan mesin Boltzmann dan metode Backpropagation untuk menghasilkan model dan hasil yang diperleh pada penelitian ini cukup menjanjikan. Penelitian [4] yang dilakukan dengan tujuan meramalkan kasus COVID-19 yang terkonfirmasi positif dan sembuh menggunakan deret waktu model TP-SMN-AR. Hasil yang diperoleh pada penelitian tersebut menunjukkan bahwa metode yang diusulkan dapat melakukan peramalan dalam mengkonfirmasi yang positif dan sembuh dari kasus COVID-19 dengan baik disejumlah negara di dunia. Penelitian [5] dilakukan dengan tujuan memprediksi tren dan kemungkinan waktu berhenti wabah COVID-19 di Kanada dan di seluruh dunia saat ini. Pada penelitian ini menggunakan jaringan memori jangka pendek (LSTM). Berdasarkan hasil dari jaringan memori jangka pendek (LSTM), diperkirakan kemungkinan titik akhir dari wabah ini adalah sekitar akhir Juni 2020 berdasarkan pada data dari awal kasus COVID19 hingga 31 Maret 2020. Dan penelitian [6] yang bertujuan untuk memprediksi kecenderungan epidemiologis prevalensi COVID-19 di Italia, Spanyol, dan Perancis, negara-negara yang paling berpengaruh di Eropa. Penelitian ini menggunakan data time series berupa data prevalensi COVID-19 dari 21 Februari 2020 hingga 15 April 2020 yang dikumpulkan dari Situs web Organisasi Kesehatan Dunia dengan menggunakan model Auto-Regressive Integrated Moving Average (ARIMA). Hasil analisis yang diperoleh pada penelitian ini dapat menjelaskan tentang tren wabah dan memberikan gambaran tentang tahap epidemiologi wilayah. Selain itu, prediksi tren prevalensi COVID-19 di Italia, Spanyol, dan Prancis dapat membantu mengambil tindakan pencegahan dan perumusan kebijakan untuk epidemi ini di negara lain.

\section{Metode Fuzzy Tsukamoto}

Logika Fuzzy merupakan teori himpunan fuzzy yang didasarkan pada fungsi keanggotaan. Pada teori himpunan fuzzy, terdapat fungsi keanggotaan dan kemudian dinyatakan dalam bentuk derajat keanggotaan. Derajat keanggotaan ini memiliki peran yang penting dalam suatu himpunan, sehingga derajat keanggotaan menjadi ciri utama dalam penalaran logika fuzzy [7].

Terdapat beberapa metode dalam penalaran menggunakan logika fuzzy, salah satunya adalah metode fuzzy Tsukamoto. Metode fuzzy Tsukamoto dalam penalarannya menggunakan penalaran monoton. Penalaran monoton digunakan sebagai dasar untuk melakukan teknik implikasi fuzzy. Metode fuzzy Tsukamoto dapat direlasikan secara sederhana dimana konsekuen pada aturan berbentuk IF-THEN, seperti persamaan berikut [8] :

IF $x$ is A THEN $y$ is $B$

\section{Metode Backpropagation}

Metode Backpropagation merupakan salah satu metode yang bersifat terawasi. Metode ini terdiri dari banyak lapisan dan biasanya digunakan oleh perceptron dalam mengubah bobot-bobot yang terhubung dengan neuron yang terdapat pada lapisan tersembunyi [9]. Pada metode backpropagation terdiri dari alur maju (forward propagation) dan alur mundur (backward propagation). Alur maju dilakukan terlebih dahulu untuk mengaktifkan neuron-neuron dengan menggunakan fungsi aktivasi, kemudian error output digunakan untuk mengubah nilai bobot-bobotnya kearah alur mundur.

\section{METODE PENELITIAN}

Pada penelitian ini melakukan kombinasi antara metode fuzzy Tsukamoto dan metode Backpropagation. Alur penelitian secara umum yang dilakukan pada penelitian ini adalah sebagai berikut :

1. Studi Pustaka

Ditahap awal pengerjaan penelitian ini, peneliti mengumpulkan informasi tentang COVID-19 serta metode yang tepat untuk pembuatan model. 
Pengumulan informasi dilakukan baik dari jurnal, buku, serta dari web terkait.

2. Pencarian Data

Tahap selanjutnya peneliti mencari data COVID19 yaitu data tentang penambahan jumlah pasien di Indonesia perharinya.

3. Pengamatan Metode

Setelah data diperoleh, tahapan berikutnya yaitu mempelajari metode yang dapat digunakan untuk membuat model dan melakukan prediksi. Pada tahap ini juga diamati pengembangan metode untuk menentukan learning rate dan momentum pada metode Backpropagation dengan menggunakan metode fuzzy Tsukamoto.

4. Mengimplementasikan Sistem

Pada tahap terakhir dilakukan pengimplementasian dengan mengaplikasikan metode Backpropagation dan metode fuzzy Tsukamoto pada data COVID-19 untuk memperoleh sebuah model prediksi kasus COVID-19 di Indonesia. Alur penelitian secara umum dapat dilihat pada Gambar 1.

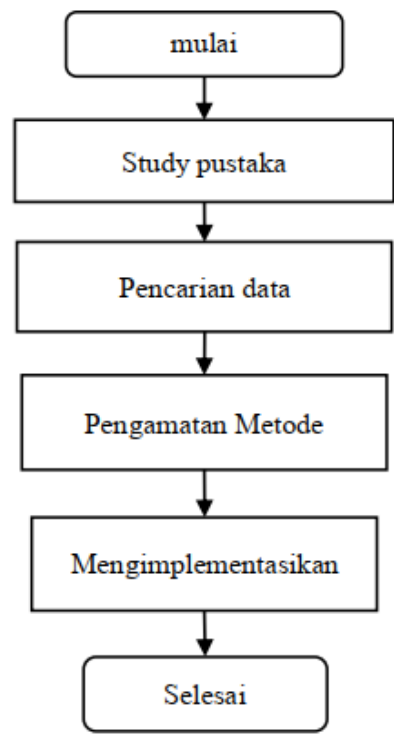

Gambar 1. Alur Penelitian Secara Umum

Metode analisa data pada penelitian ini menggunakan metode fuzzy Tsukamoto dan metode Backpropagation. Diagram alir metode fuzzy Tsukamoto dapat dilihat pada Gambar 2.

Gambar 2 merupakan diagram alir metode fuzzy Tsukamoto yang digunakan untuk mendapatkan nilai learning rate dan momentum. Adapun langkah untuk mendapatkan nilai learning rate dan momentum tersebut adalah menentukan himpunan keanggotaan fuzzy dari inputan yaitu jumlah data dan banyaknya iterasi yang digunakan untuk pembelajaran pada metode Backpropagation. Langkah berikutnya yaitu menetapkan aturan logika Fuzzy atau rule, serta menetapkan predikat dari aturan tersebut. Langkah selanjutnya setelah pembentukan aturan adalah Defuzzyfikasi, dimana pada langkah ini menggunakan metode defuzzyfikasi Roulette Wheel sehingga diperoleh output yaitu learning rate dan momentum.

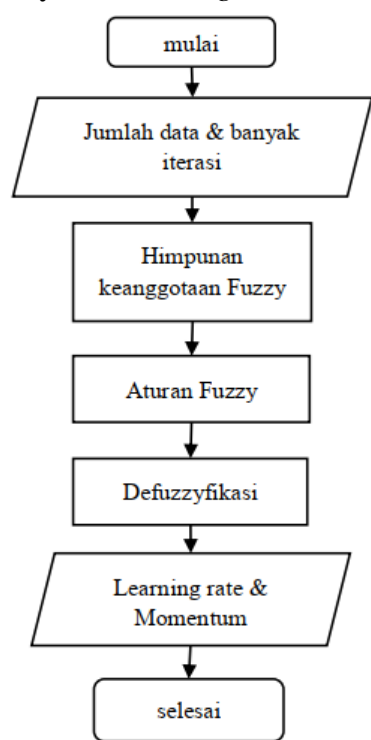

Gambar 2. Diagram Alir Metode Fuzzy Tsukamoto

Setelah diperoleh learning rate dan momentum, maka hasil tersebut digunakan pada metode Backpropagation. Pada metode Backpropagation memiliki 2 alur, yaitu alur maju dan alur mundur. Arsitektur jaringan metode Backpropagation secara umum dapat dilihat pada Gambar 3.

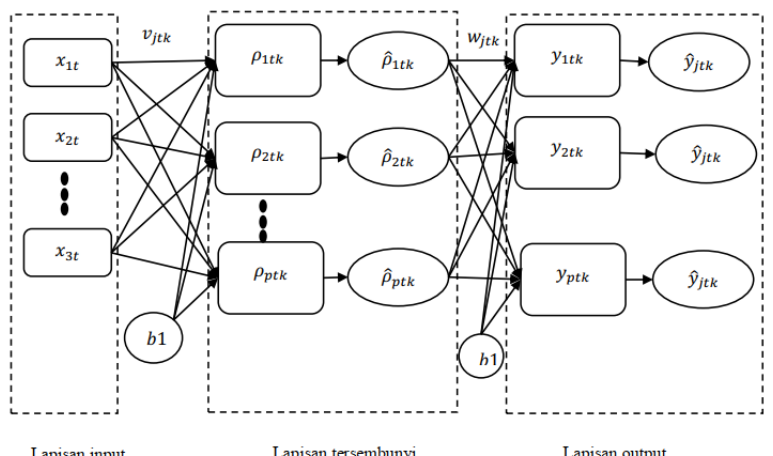

Gambar 3. Arsitektur Jaringan Metode Backpropagation Secara Umum

Gambar 3 merupakan arsitektur secara umum dengan menggunakan satu lapisan tersembunyi dengan banyak neuron. Adapun algoritmanya yaitu sebagai berikut :

Alur maju [10] :

1. Setiap neuron pada lapisan input $x_{\text {it }}$ $(i=1,2,3, \ldots, n$ dan $t=1,2,3, \ldots, l)$ di masukan ke lapisan tersembunyi. 
2. Sinyal dari lapisan input $x_{\text {it }}$ diproses di lapisan tersembunyi dengan menggunakan persamaan berikut:

$$
\rho_{j t k}=b 1_{j t k}+\sum_{i=1}^{n} x_{i t} v_{i j t k}
$$

Setelah diperoleh nilai $\rho$ selanjutnya diaktivasi dengan persamaan sigmoid biner berikut: $\hat{\rho}_{j t k}=\frac{1}{1+g^{\rho_{j} t k}}$

(3)

3. Sinyal dari lapisan tersembunyi dikirimkan ke neuron-neuron dilapisan output kemudian dilapisan output diproses dengan menggunakan persamaan sebagai berikut:

$y_{j t k}=b 2_{j t k}+\sum_{i=1}^{n} \hat{P}_{j t k} v_{i j t k}$

(4)

Setelah diperoleh $y_{j t k}$, selanjutnya untuk mendapatkan outpunya digunakan fungsi aktivasi purelin yaitu sebagai berikut:

$\hat{y}_{j t k}=f\left(y_{j t k}\right)$

Alur mundur :

Setelah diperoleh alur maju, langkah selanjutnya adalah alur mundur dengan menggunakan evaluasi dari alur maju. Lankah-lankah alur mundur untuk perbaikan bobot adalah sebagai berikut :

1. Bobot-bobot yang menghubungkan antar neuron dimasing-masing lapisan diperbaiki berdasarkan error dari output pada alur maju yang dapat diperoleh dengan menggunakan persamaan sebagai berikut:

$\delta_{t k}=\left(T_{t}-y_{t k}\right) f^{0}\left(y_{j k k}\right)$

(6)

setelah di peroleh $\delta_{t k}$ digunakan untuk mendapatkan $\Delta w_{j t k}$, dengan disubstitusikan kepersamaan berikut:

$\Delta w_{j t k}= \begin{cases}\alpha \delta_{t k} \hat{\rho}_{j t k}, & \text { epoch }=1 \\ m c\left(\Delta w_{j t k}(\text { epoch sebelumnya })+\alpha \delta_{t k} \hat{\rho}_{j t k},\right. & \text { epoch }>1\end{cases}$

Kemudian untuk mendapatkan bobot bias baru pada lapisan output digunakan persamaan berikut:

$\Delta b 2_{t k}= \begin{cases}\alpha \delta_{t k}, & \text { epoch }=1 \\ m c\left(\Delta b 2_{t k}(\text { epoch sebelumnya })+\alpha \delta_{t k},\right. & \text { epoch }>1\end{cases}$

2. Untuk mendapatkan bobot baru yang menghubungkan antara lapisan input dengan neuron dilapisan tersebunyi dengan terlebih dahulu mencari $\delta_{-} i n_{j t k}$ dan $\delta_{j t k}$ dengan persamaan sebagai berikut:

$\delta_{-} i n_{j t k}=\sum_{j=1}^{p} \delta_{t k} w_{j t k}$

$\delta_{j t k}=\delta_{i n_{j k k}} f^{\prime}\left(\rho_{j t k}\right)$

Kemudian langkah selanjutnya adalah mendapatkan bobot yang menghubungkan antara lapisan input dengan lapisan tersembunyi dengan menggunakan persamaan berikut:

$\Delta v_{i j t k}= \begin{cases}\alpha \delta_{j t k} x_{j t}, & \text { epoch }=1 \\ m c\left(\Delta v_{i j t k}(\text { epoch sebelumnya })+\alpha \delta_{j t k} x_{j t},\right. & \text { epoch }>1\end{cases}$

(11)
Kemudian untuk mendapatkan bobot bias baru pada lapisan tersembunyi digunakan persamaan berikut:

$\Delta b 1_{j t k}= \begin{cases}\alpha \delta_{j t k}, & \text { epoch }=1 \\ m c\left(\Delta b 1_{j t k}(\text { epoch sebelumnya })+\alpha \delta_{j t k},\right. & \text { epoch }>1\end{cases}$

Tahap berikutnya adalah mendapatkan bobot baru dengan mensubstitusikan $\Delta w_{j t k}, \Delta v_{i j t k}, \Delta b 2_{t k}$, dan $\Delta b 1_{j t k}$ kepersamaan berikut:

$$
\begin{aligned}
& w_{j t k}(\text { baru })=w_{j t k}(\text { lama })+\Delta w_{j t k} \\
& b 2_{t k}(\text { baru })=b 2_{t k}(\text { lama })+\Delta b 2_{t k} \\
& v_{i j t k}(\text { baru })=v_{j j t k}(\text { lama })+\Delta v_{i j t k} \\
& b 1_{j t k}(\text { baru })=b 1_{j t k}(\text { lama })+\Delta b 1_{j t k}
\end{aligned}
$$

\section{HASIL DAN PEMBAHASAN}

1. Data

Banyaknya data yang digunakan pada penelitian ini adalah 71 hari dari tanggal 2 maret 2020 sampai tanggal 18 mei 2020. Grafik penambahan kasus COVID-19 setiap harinya dpaat dilihat pada Gambar 4.

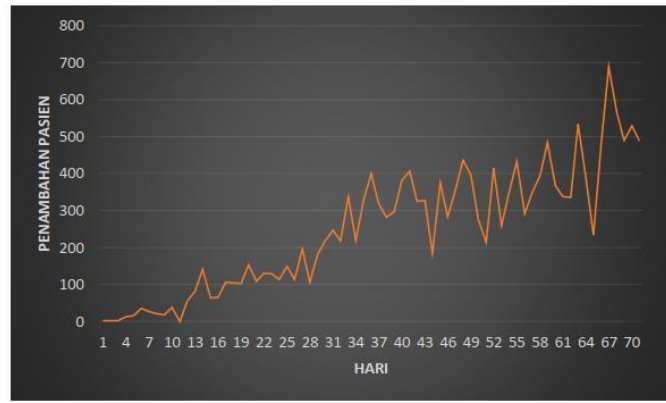

Gambar 4. Grafik Penambahan COVID-19 di Indonesia

Gambar 4 merupakan grafik penambahan kasus COVID-19 di Indonesia. Sumber data pada penelitian ini diperoleh dari [1]. Pada data tersebut nilai penambahan pasien covid-19 di Indonesia paling besar yaitu 689 orang perharinya dan terdapat satu hari tidak ada penambahan pasien. Rata-rata penembahan jumlah pasien yaitu sebesar 250,17 atau kurang lebih sebanyak 251 orang per harinya, median sebesar 253,5 , variansi data yaitu 27261,33251 , dan standar deviasi yaitu sebesar 166,197. Dari akumulasi penambahan pasien setiap harinya dari 2 maret 2020 sampai 18 mei 2020 yaitu sebanyak 17.512 pasien.

Adapun tabel pengelompokkan data penambahan kasus COVID-19 ini dapat dilihat pada Tabel 1.

Tabel 1. Data Pengelompokkan Penambahan Kasus COVID-19.

\begin{tabular}{lll}
\hline No & Interval & Frekuensi \\
\hline 1 & $0-97$ & 15
\end{tabular}




\begin{tabular}{lll}
\hline 2 & $98-195$ & 14 \\
3 & $196-293$ & 12 \\
4 & $294-391$ & 15 \\
5 & $392-489$ & 9 \\
6 & $490-587$ & 5 \\
7 & $588-685$ & 0 \\
8 & $686-783$ & 1 \\
\hline
\end{tabular}

Tabel 1 tersebut menggambarkan bahwa jumlah penambahan paling banyak berada direntang 0-91 dan direntang 294-391 yaitu masing-masing sebanyak 15 data.

Penelitian ini menggunakan data time series untuk membuat model peramalan penambahan pasien COVID-19 setiap harinya, prediksi tersebut berdasarkan data tiga hari sebelumnya. Data yang digunakan untuk pelatihan pada metode Backpropagation yaitu sebanya 58 data, kemudian untuk data testing digunakan 10 data yaitu data pada tanggal 6 Mei 2020 sampai 18 Maret 2020.

2. Metode Fuzzy Tsukamoto

Pada penelitian ini dilakukan pembentukkan himpunan keanggotaan fuzzy dengan menggunakan fuzzy Tsukamoto. Himpunan keanggotaan fuzzy pada penelitian ini dapat diihta pada Gambar 5,6,7, dan 8 .

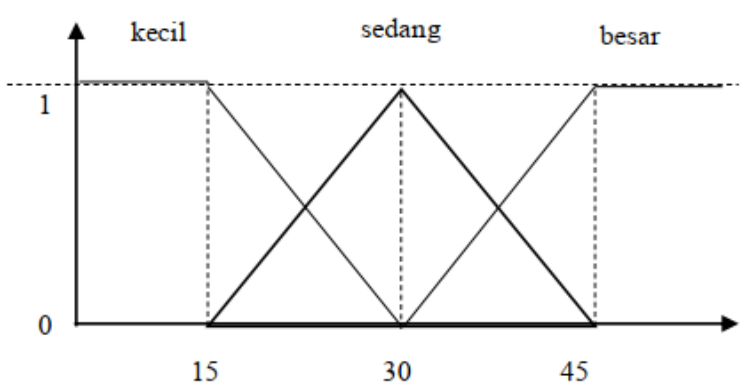

Gambar 5. Fungsi Keanggotaan Fuzzy Banyak Data

$$
\begin{aligned}
& \mu_{\text {kecil }}(\delta)=\left\{\begin{aligned}
1, & \delta<15 \\
\frac{30-\delta}{15}, & 15 \leq \delta \leq 30 \\
0, & \delta>30
\end{aligned}\right. \\
& \mu_{\text {sedang }}(\delta)=\left\{\begin{array}{cc}
1_{v} \delta<15 \text { dan } \delta>45 \\
\frac{\delta-15}{15}, & 15 \leq \delta \leq 30 \\
\frac{45-\delta}{15}, & 30<\delta \leq 45
\end{array}\right. \\
& \mu_{\text {besar }}(\delta)=\left\{\begin{aligned}
0, & \delta<30 \\
\frac{8-a 0}{15}, & 30 \leq \delta \leq 45 \\
1_{v} & \delta>45
\end{aligned}\right.
\end{aligned}
$$

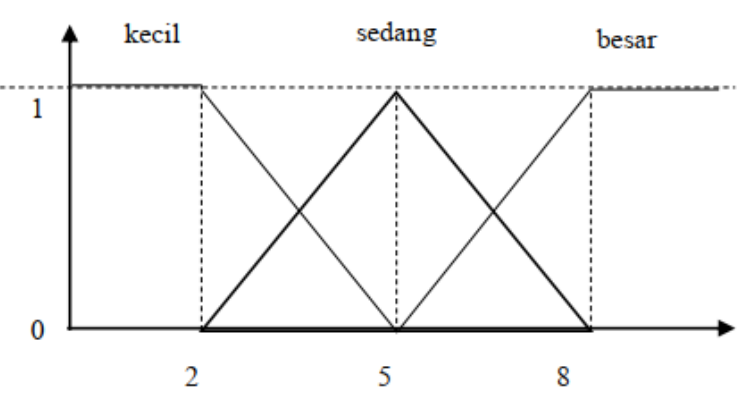

Gambar 6. Fungsi Keanggotaan Fuzzy Banyak

$$
\begin{gathered}
\mu_{\text {gedikit }}(\gamma)=\left\{\begin{array}{cc}
\text { Variabel Bebas } \\
1_{s} & \gamma<2 \\
\frac{5-\gamma}{a}, & 2 \leq \gamma \leq 5 \\
0, & \gamma>5
\end{array}\right. \\
\mu_{\text {gedang }}(\gamma)=\left\{\begin{array}{cc}
0, y<2 \text { dan } \gamma>8 \\
\frac{\gamma-2}{a}, \quad 2 \leq \gamma \leq 5 \\
\frac{g-\gamma}{a}, & 5<\gamma \leq 8
\end{array}\right.
\end{gathered}
$$

$\mu_{\text {banyak }}(\gamma)=\left\{\begin{array}{rc}0, & \gamma<5 \\ \frac{\gamma-5}{15}, & 5 \leq \gamma \leq 8 \\ 1, & y>8\end{array}\right.$

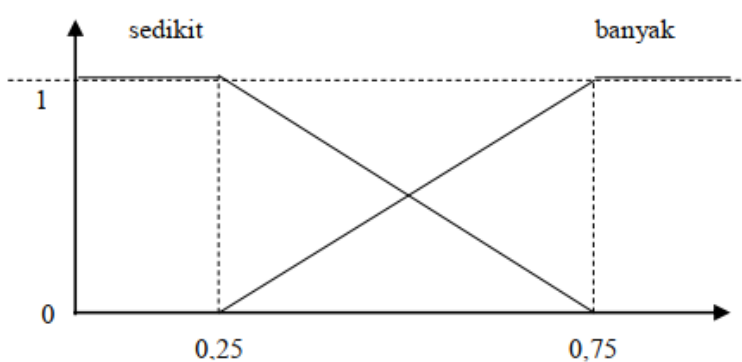

Gambar 7. Himpunan keanggotaan Fuzzy Momentum

$$
\begin{gathered}
\mu_{\text {gedikit }}(\theta)=\left\{\begin{array}{rc}
1_{s} & \theta<0,25 \\
0,55-\theta & 0,25 \leq \theta \leq 0,75 \\
0, & \theta>0,75
\end{array}\right. \\
\mu_{\text {banyak }}(\theta)=\left\{\begin{array}{rc}
0, & \theta<0,25 \\
\frac{\theta-0,25}{0,5}, & 0,25 \leq \theta \leq 0,75 \\
1_{s} & \theta>0,75
\end{array}\right.
\end{gathered}
$$

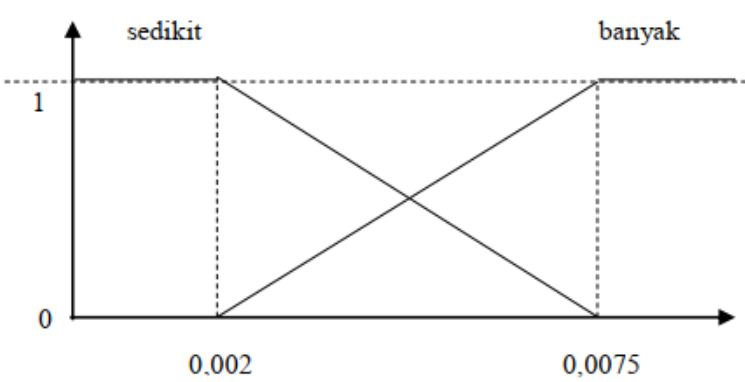

Gambar 8. Fungsi Keanggotaan Fuzzy Learning Rate 


$$
\begin{gathered}
\mu_{\text {sedikit }}(\omega)=\left\{\begin{array}{cc}
1_{s} & \omega<0,0025 \\
\frac{0,0075-\omega}{0,005}, & 0,0025 \leq \omega \leq 0,0075 \\
0, & \omega>0,0075
\end{array}\right. \\
\mu_{\text {banyak }}(\omega)=\left\{\begin{array}{cc}
0, & \omega<0,0025 \\
\frac{\omega-0,025,}{0,005}, & 0,0025 \leq \omega \leq 0,0075 \\
1_{w} & \omega>0,0075
\end{array}\right.
\end{gathered}
$$

Setelah himpunan keanggotaan fuzzy maka diperoleh komposisi aturan, yaitu sebagai berikut :

1) IF jumlah data (kecil) $A N D$ variabel bebas (sedikit) THEN momentum (sedikit) AND learning rate (sedikit)

2) IF jumlah data (kecil) $A N D$ variabel bebas (sedang) THEN momentum (sedikit) AND learning rate (sedikit)

3) IF jumlah data (kecil) AND variabel bebas (banyak) THEN momentum (sedikit) AND learning rate (sedikit)

4) IF jumlah data (sedang) AND variabel bebas (sedikit) THEN momentum (sedikit) AND learning rate (banyak)

5) IF jumlah data (sedang) AND variabel bebas (sedang) THEN momentum (banyak) AND learning rate (banyak)

6) IF jumlah data (sedang) $A N D$ variabel bebas (banyak) THEN momentum (banyak) AND learning rate (banyak)

7) IF jumlah data (besar) AND variabel bebas (sedikit) THEN momentum (banyak) AND learning rate (banyak)

8) IF jumlah data (besar) AND variabel bebas (sedang) THEN momentum (banyak) AND learning rate (banyak)

IF jumlah data (besar) $A N D$ variabel bebas (banyak) THEN momentum (banyak) AND learning rate (banyak).

Dan kemudian dilakukan defuzzyfikasi. Untuk memperoleh output defuzzyfikasi menggunakan hasil dari komposisi aturan fuzzy. Defuzzyfikasi yang digunakan yaitu metode rata-rata terbobot dengan menggunakan persamaan :

$$
Z=\frac{\sum_{i=1}^{n} Z_{i} E_{i}}{\sum_{i=1}^{m} \varepsilon_{i}}
$$

Hasil simulasi pada metode fuzzy Tsukamoto untuk menghasilkan learning rate dan momentum pada penelitian ini menggunakan MatLab dan diperoleh learning rate sebesar 0,0075 dan momentum sebesar 0,75 . Source code yang digunakan untuk menghasilkan learning rate dan momentum menggunakan meted fuzzy Tsukamoto pada penelitian ini dapat dilihat pada listing program berikut :

Listing Program Metode Fuzzy Tsukamoto
\begin{tabular}{|l} 
clear all; \\
clc; \\
xl= input ('Enter right end point, $\mathrm{x} 1$ : ' '); \\
x2= input ('Enter no. of subintervals, x2: '); \\
ohimpunan keanggotaan fuzzy untuk x1
\end{tabular}

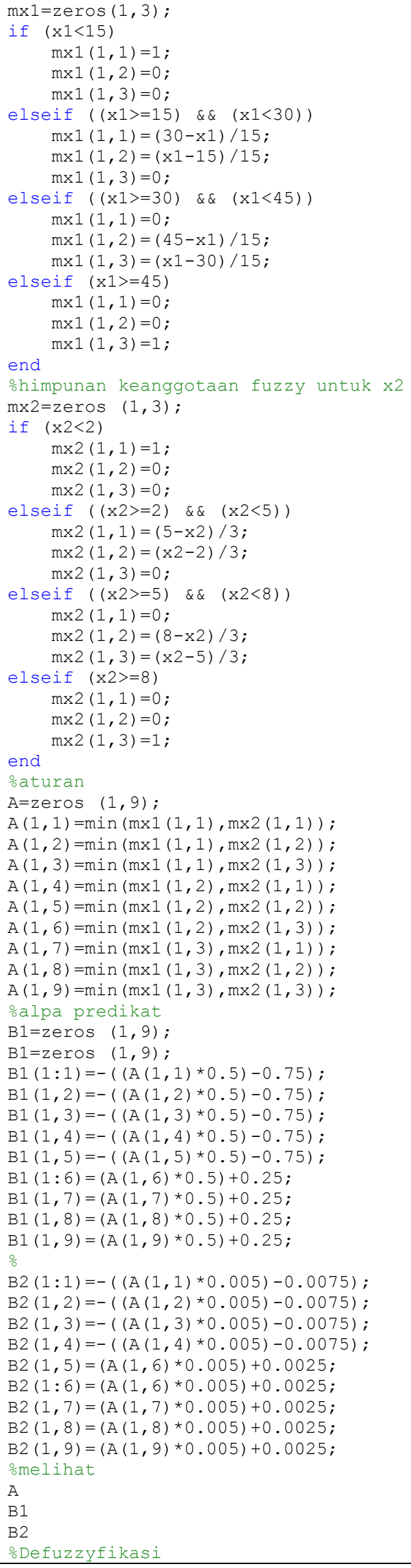




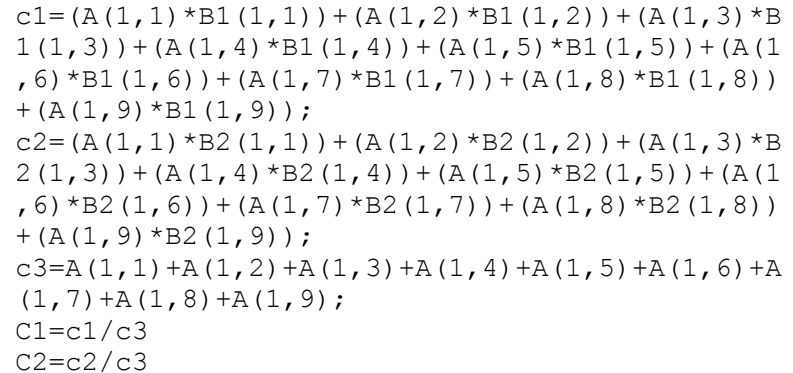

\section{Metode Backpropagation}

Setelah diperoleh learning rate dan momentum maka selanjutnya mencari model untuk prediksi penambahan kasus COVID-19 di Indonesia menggunakan metode Backpropagation. Simulasi model diperoleh dengan menggunakan data testing. Berdasarkan langkah-langkah Backpropagation dengan lapisan input menggunakan satu neuron, satu lapisan tersembunyi dengan satu neuron, dan lapisan output dengan satu neuron. Arsitektur jaringan untuk penelitian ini dapat dilihat pada Gambar 9.

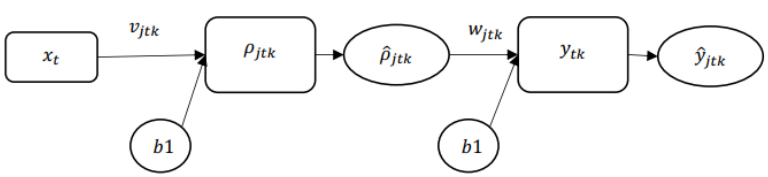

Gambar 9. Arsitektur Jaringan Backpropagation

Berdasarkan arsitektur jaringan pada Gambar 9, dimana epoch 1000 , learning rate 0,0075 , dan momentum 0,75 tersebut dengan menggunakan program MatLab diperoleh hasil seperti pada Gambar 10.
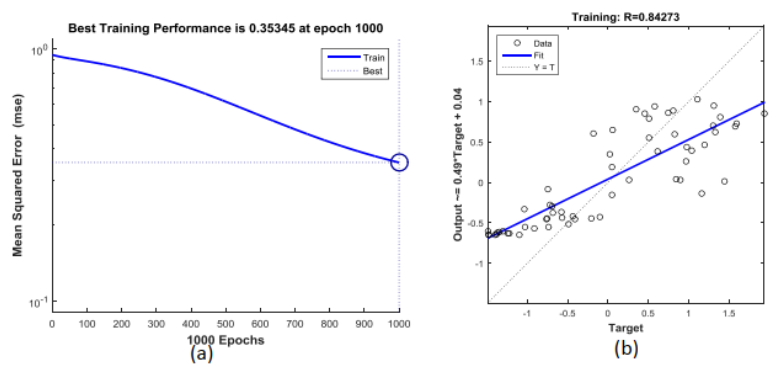

Gambar 10. Hasil Pelatihan Metode Backpropagation

Pada Gambar 10 (a) terlihat bahwa pembelajaran dari epoch 0 sampai epoch 1000 dengan mean squared error (MSE) menunjukan hasil MSE yang mendekati 0 . Sedangkan pada Gambar 10 (b) menunjukan persamaan regresi dengan hasil yang cukup baik yaitu dengan $R=0,84278$, terlihat bahwa garis regresi mengikuti pola data.
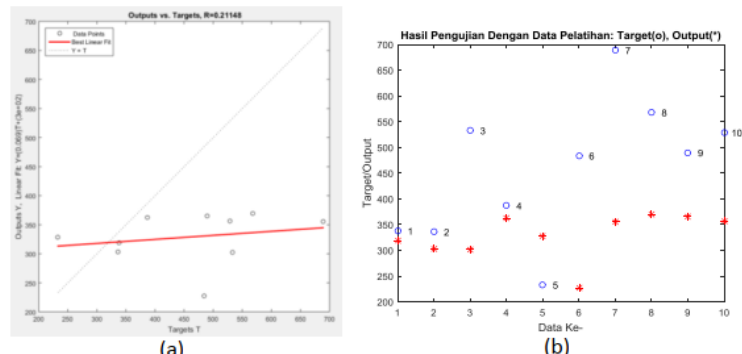

Gambar 11. Hasil Simulasi Model Backpropagation

Gambar 11(a) tersebut menunjukan model regresi pada data testing yang menunjukan garis regresi yang mengikuti pola data testing. Gambar 11(b) merupakan hasil perkiraan dengan model Backpropagation yang sudah di peroleh dengan target atau hasil sebenarnya pada data, dimana MSE untuk data normalisasi adalah 1,632337 , sehingga diperoleh model penambahan kasus COVID-19 di Indonesia dengan menggunakan metode Backpropagation yang di kombinasikan dengan metode Fuzzy Tsukamoto yaitu sebagai berikut

$\hat{y}=-0,7474+\left(1,8804\left(\frac{1}{1+e^{-0,5004+(1,6779)\left(x_{\mathrm{t}}\right)}}\right)\right)$

\section{KESIMPULAN}

Berdasarkan penelitian dan implementasi metode fuzzy Tsukamoto dan metode Backpropagation yang telah dilakukan, dapat disimpulkan bahwa,

1. Metode fuzzy Tsukamoto dapat digunakan untuk menghasilkan nilai learning rate dan momentum.

2. Metode fuzzy Tsukamoto dan metode Backpropagation dapat dikombinasikan untuk memperoleh sebuah model penambahan kasus COVID-19 di Indonesia dengan menggunakan percobaan epoch 1000 , learning rate 0,0075 , dan momentum 0,75 , sehingga diperoleh nilai koefisien korelasi atau $R=0,84278$ dan simulasi prediksi menghasilkan nilai MSE untuk data normalisasi adalah 1,632337 .

3. Sehingga diperoleh model penambahan kasus COVID-19 di Indonesia dengan menggunakan metode Backpropagation yang di kombinasikan dengan metode Fuzzy Tsukamoto yaitu sebagai berikut :

$$
\hat{y}=-0,7474+\left(1,8804\left(\frac{1}{\left.\left.1+e^{-0,5004+(1,6779)\left(x_{\mathrm{t}}\right)}\right)\right)}\right.\right.
$$

\section{SARAN}

Penelitian yang dilakukan saat ini hanya menggunakan 1 kali percobaan pada arsitektur jaringan Backpropagation, sehingga untuk penelitian selanjutnya dapat menggunakan lebih banyak 
percobaan agar dapat memperoleh model yang lebih baik.

\section{DAFTAR PUSTAKA}

[1] "Data COVID-19." [Online]. Available: https://data.world/shad/covid-analysis.

[2] "WHO." [Online]. Available: https://www.who.int/health-topics/.

[3] R. Hrasko, A. G. C. Pacheco, and R. A. Krohling, "Time series prediction using restricted boltzmann machines and backpropagation," Procedia Comput. Sci., vol. 55, no. Itqm, pp. 990-999, 2015, doi: 10.1016/j.procs.2015.07.104.

[4] M. Maleki, M. R. Mahmoudi, D. Wraith, and K. H. Pho, "Time series modelling to forecast the confirmed and recovered cases of COVID-19," Travel Med. Infect. Dis., no. March, p. 101742, 2020, doi: 10.1016/j.tmaid.2020.101742.

[5] V. K. R. Chimmula and L. Zhang, "Time Series Forecasting of COVID-19 transmission in Canada Using LSTM Networks.," Chaos. Solitons. Fractals, vol. 135, p. 109864, 2020, doi: 10.1016/j.chaos.2020.109864.

[6] Z. Ceylan, "Estimation of COVID-19 prevalence in Italy, Spain, and France," Sci. Total Environ., vol. 729, p. 138817, 2020, doi: 10.1016/j.scitotenv.2020.138817.

[7] S. Kusumadewi and H. Purnomo, Aplikasi Logika Fuzzy untuk Pendukung Keputusan. Yogyakarta: Graha Ilmu, 2013.

[8] F. S. SJ, Himpunan dan Logika Kabur serta Aplikasinya. Yogyakarta: Graha Ilmu, 2006.

[9] S. Kusumadewi, Membangun Jaringan Syaraf Tiruan menggunakan MATLAB \& EXCEL LINK, Edisi Pert. Yogyakarta: Graha Ilmu, 2013.

[10] F. S. D. Arianto, M. N. Mara, and N. N. Debataraja, "PREDIKSI pH AIR HUJAN DI KALIMANTAN BARAT DENGAN METODE BACKPROPAGATION," vol. 04, no. 3, pp. 397-406, 2015. 